\title{
Enrichment, isolation and biodegradation potential of psychrotolerant polychlorinated-biphenyl degrading bacteria from the Kongsfjorden (Svalbard Islands, High Arctic Norway)
}

Maria Papale ${ }^{\mathrm{a}}$, Stefania Giannarelli ${ }^{\mathrm{b}}$, Sandro Francesconi ${ }^{\mathrm{b}}$, Gaetano Di Marco ${ }^{\mathrm{c}}$, Anu Mikkonen $^{\mathrm{d}}$, Antonella Conte ${ }^{\mathrm{a}}$, Carmen Rizzo ${ }^{\mathrm{a}}$, Emilio De Domenico ${ }^{\mathrm{a}}$, Luigi Michaud ${ }^{\mathrm{a}} \dagger$, Angelina Lo Giudice, ${ }^{\text {a,e\# }}$

\footnotetext{
a Department of Chemical, Biological, Pharmaceutical and Environmental Sciences (ChiBioFarAm), University of Messina, Messina, Italy;

${ }^{\mathrm{b}}$ Department of Chemistry and Industrial Chemistry, University of Pisa, Pisa, Italy;

${ }^{\mathrm{c}}$ Istituto per i Processi Chimico Fisici, National Research Council (IPCF-CNR), Messina, Italy;

${ }^{\mathrm{d}}$ Department of Biological and Environmental Sciences, University of Jyvaskyla, Jyvaskyla, Finland;

${ }^{\mathrm{e}}$ Institute for the Coastal Marine Environment, National Research Council (IAMC-CNR), Messina, Italy
}

Running head: PCB-degrading bacteria from the Arctic Kongsfjorden

\#Address correspondence to Angelina Lo Giudice, angelina.logiudice@iamc.cnr.it $\dagger$ Deceased.

This paper is dedicated to the memory of Simon Herniman who efficiently and enthusiastically supported us in lab and field activities during our stay in Ny-Alesund. 


\begin{abstract}
Persistent organic pollutants (POPs), such as polychlorinated biphenyls (PCBs), have been detected in abiotic Arctic matrices: surface sediments and- sea-water-and ice- from coastal areas in the Kongsfjorden were collected and analyzed. Levels of PCBs varied depending on sampling sites. Total PCBs concentrations were between 11.,63 (site C2W) and $27, .69 \mathrm{pg} \mathrm{l}^{-1}$ (site AW). These levels were comparable to those reported previously in lake sediments from the northern Svalbard.

The occurrence and biodegradation potential of cold-adapted PCB-oxidizing bacteria in seawater and sediment along the fjord was also evaluated. After enrichment with biphenyl, 246 isolates were obtained with 45 of them that were able to grow in the presence of the PCB mixture Aroclor 1242, as the sole carbon source. The catabolic gene bphA was harbored by 17 isolates with affiliates to the genera Algoriphagus, Devosia and Salinibacterium that have been never reported as able to utilize PCBs, thus deserving further investigation. The total removal of Aroclor 1242 and selected PCB congeners, was evaluated at 4 and $15^{\circ} \mathrm{C}$ for eight $b p h \mathrm{~A}$-harboring isolates and Gelidibacter sp. DS10. With few exceptions, tested strains showed greater efficiency at 15 than at $4{ }^{\circ} \mathrm{C}$. Isolates were able to reduce most chromatographic peaks by more than $50 \%$, with some di- and trichlorobiphenyls that were quite totally removed (>90\%).
\end{abstract}

Key-words: Cold-adapted bacteria, polychlorobiphenyls, contamination level, Arctic fjord, biodegradation 


\section{INTRODUCTION}

Polychlorinated biphenyls (PCBs) are included in the list of persistent organic pollutants (POPs) that have a long-lifetime in the environment. Due to their chemical and physical characteristics, PCBs were produced between 1929 and late 1970s and used in several industrial applications (Ceccarini and Giannarelli, 2007). They are also emitted from a number of anthropogenic sources (such as utilization, disposal and accidental releases of products or materials containing these compounds). The incidental or unwanted formation of PCBs e.g., de novo synthesis in combustion processes, thermal process of chlorine-containing materials or combustion of by-products (such as fuel combustion, waste incineration, the oxidation of iron, spills, accidents and emergencies) should be also treated as a possible environmental threat (Kim et al., 2004; Van Gerven et al., 2004; Shin et al., 2006; Sabin et al., 2010). Despite the fact that the use of these chemicals has either been phased-out or restricted, they are still found in the environment at levels that, due to their bioaccumulation and biomagnification behaviors, may cause negative effects to the human and animal health (Cecinato et al., 2000; Jiao et al., 2009; Wang et al., 2009; Lehtinen et al., 2013).

The issue of the transport and fate of PCBs in remote areas, such as the Arctic and Antarctica, has received increasing attention during the past decade (Fuoco et al., 2009; Bengtson Nash, 2011; Polkowska et al., 2011). The occurrence of these contaminants in the Arctic environment is the result of several years of transport. Pollutants concentrated in the oceanic surface microlayer may also be incorporated in drifting ice, while pollutants deposited from the atmosphere accumulate on the snow and ice surface (Fuoco et al., 2013; Garmash et al., 2013). Ice melts most extensively along the marginal ice 
zone. As the Arctic is a region of intense biological activity, pollutants, often transported far from entrainment areas, are released directly into the surface water where they may easily enter the food chain. As a result of these processes, drifting sea ice may play a role in long-range redistribution of contaminants in the Arctic, which is believed to act as a sink for such chemicals (Garmash et al., 2013).

Once in the environment, the fate of PCBs is strictly linked to bacteria which represent the first step in the transfer of toxic compounds to higher trophic levels (Gillan et al., 2005; Lo Giudice et al., 2013). Bacteria possess genetic and biochemical capacities for remediation of PCB pollution. The biodegradation of certain, usually less chlorinated, PCB congeners has been reported for several microorganisms elsewhere in the world. However, cold-adapted PCB-degraders have been rarely isolated from cold environments, such as Arctic soils (Mohn et al., 1997; Master and Mohn, 1998) and Antarctic seawater and sediment (Yakimov et al., 1999; Michaud et al., 2007; Lo Giudice et al., 2013). Such isolates could represent a valid alternative to classical methods used for PCB degradation that are generally expensive and inefficient, and can produce secondary sources of pollution such as dibenzofurans and polychlorinated dibenzodioxins (Yang et al., 2004). As previously reported, in cold environments temperature acts as a major determining factor in the biodegradation process, and specificity of cells for some PCB congeners is generally different at different temperatures (Lambo and Patel, 2006; Michaud et al., 2007; Master and Mohn, 2001). This is often strictly linked to the expression of genes coding for enzymes responsible for PCB degradation.

In this context, the present study was aimed at both investigating the occurrence of coldadapted PCB-oxidizing bacteria in seawater and sediment along the Kongsfjorden 
(Svalbard Islands, High Arctic Norway) and analyzing the- biodegradation potential at 4 and $15^{\circ} \mathrm{C}$ of bacterial isolates, by paying particular attention to those belonging to genera that have been never reported as PCB degraders.

\section{MATERIALS AND METHODS}

Sampling area. The Kongsfjorden $\left(79^{\circ} \mathrm{N}, 12^{\circ} \mathrm{E}\right)$ is a glacial fjord located on the west coast of the Svalbard Archipelago (Arctic Norway). It is about $20 \mathrm{~km}$ long and its width varies from 4 to $10 \mathrm{~km}$ (Svendsen et al., 2002). The fjord, whose volume was estimated to be $29.4 \mathrm{~km}^{3}$ (Ito and Kudoh, 1997), has different depth zones: the outer part, in connection with the ocean, is the deepest, while the inner area is approximately around $100 \mathrm{~m}$ in depth (Hop et al., 2002). The Kongsfjorden is an open fjord as the water flow is not obstructed by sills at its entrance. The internal circulation is governed by an arm of seawater saltier and warmer, deriving from the Atlantic Ocean, which enters from the south. During summer the water mass is mixed into the fjord with cold and less salty water which derives from melting glaciers. Thus, the outer fjord is influenced by oceanographic conditions and the inner fjord is influenced by large tidal glaciers (Svendsen et al., 2002). During winter the movement of water is reduced due the ice formation on the surface. Despite what might expect at this high latitude, Atlantic influence makes this fjord sub-Arctic instead Arctic.

Sampling and preliminary treatment of samples. Sampling of seawater and sediment was carried out at seven stations along the coast of the Kongsfjorden (Figure 1) in summer 2009. Samples were named using the letters A to E followed by the suffix S (for 
sediment samples) or W (for water samples). In particular, three samples were collected from the site C (samples C1, C2 and C3) next to the Ny-Ålesund research village.

All samples were aseptically collected and preliminary processed after sampling (approximately $2 \mathrm{~h}$ ) in the laboratory of the Natural Environment Research Council (NERC) Station (Great Britain) in Ny-Ålesund, as described in the following sections. Temperature, $\mathrm{pH}$, dissolved oxygen, salinity, conductibility and temperature of water were recorded in water at each sampling point (Table 1).

PCB concentration in natural samples. Water samples were collected, in triplicate, using 25-L stainless steel containers. Sediment samples were collected using a precleaned stainless steel bailer and stored in pre-cleaned glass jars until analysis. Chemical analyses to determine the PCB concentration in water and sediments samples were carried out by GC-MS. The analytical procedure for PCB determination in water samples has been described elsewhere (Zoccolillo et al., 2004). The method consisted of a high efficiency liquid-liquid extraction with $n$-hexane followed by a gas chromatographic analysis with a mass spectrometric confirmation. After collection, water samples (about $20 \mathrm{~L}$ each) were immediately subjected to liquid-liquid extraction. The extraction step allowed obtaining about 1000-fold concentration enrichment (the rate water/n-hexane was 1000/1).

A 10-L flat-bottomed flask, a modified flask stopper and a micro extractor were employed for the extraction. A stirring device (MR 3000 D-230 V/50HZ, Heidolph Elektro, Germany) and a stirring magnet (7SWN672 CYL 50×8 mm, Bibby Sterilin Ltd, England) were employed to spread the organic extracting phase into the water sample. 
Pesticide Grade $n$-hexane (J.T. Baker, Netherlands) was used as extracting solvent. Stirring was maintained for $30 \mathrm{~min}$, then the mixture was left still for $30 \mathrm{~min}$ to allow the separation between the organic and the aqueous phase. Subsequently, organic extracts were maintained at $-20^{\circ} \mathrm{C}$ and sent to Italy for instrumental analysis. Samples of $n$-hexane were used as controls. The conservation at $-20^{\circ} \mathrm{C}$ guaranteed the preservation of organic extracts' original composition, as confirmed by tests made on standard solutions stored at the same conditions.

Sediment extraction was carried out according to Jensen et al. (1997; EPA Method 3660 B: Sulfur Cleanup). An aliquot of the wet sediment sample (2-3 g) was dried at $110^{\circ} \mathrm{C}$ for sediment dry weight estimation. Sediment $(15-20 \mathrm{ml})$ was transferred into a weighed centrifuge tube $(60 \mathrm{ml})$ and centrifuged for $15 \mathrm{~min}$ at $1000 \times \mathrm{g}$ (2500 rpm; Rotofix $32 \mathrm{~A}$, Hettich). The water was discarded, the tube weighed again, and the wet weight calculated. $20 \mathrm{ml}$ of a mixture of acetone: hexane (3:1) was added to the sample and this was posed in a ultrasonic bath (Sonorex super $10 \mathrm{p}$, Bandelin) at $60^{\circ} \mathrm{C}$ for $30 \mathrm{~min}$.

The supernatant was taken and the sediment was resubmitted to the same treatment. The two organic phases were then combined and placed in a centrifugal evaporator (Jouan RC10.22 series Vacuum Concentrator). After a first concentration the residue was dissolved in trimethyl pentane $(4 \mathrm{ml})$ and again placed in the centrifugal evaporator to obtain a final volume of $2 \mathrm{ml}$.

The trimethyl pentane extract $(2 \mathrm{ml})$ was shaken with 2-propanol $(1 \mathrm{ml})$ and the TBAsulfite reagent (solution of tetrabutylammoniumhydrogen sulfate saturated with sodium sulfite, Sigma-Aldrich) $(1 \mathrm{ml})$ for $1 \mathrm{~min}$. If the sodium sulfite precipitate disappeared, more was added in $100 \mathrm{mg}$ portions until a solid residue remained after repeated shaking. 
Water $(5 \mathrm{ml})$ was added and the tube was shaken for another minute, followed by centrifugation, and the trimethyl- pentane phase was transferred to a test tube. In accord with the method EPA 3620C to separate analytes from non-polar or slightly polar interfering compounds was used a chromatographic column containing the adsorbing solid phase (Florisil) with a top layer of sodium sulfate, to remove any traces of water (Dual Layer Florisil ${ }^{\circledR} / \mathrm{Na}_{2} \mathrm{SO}_{4}$ SPE Tube $2 \mathrm{~g} / 2 \mathrm{~g} / 6 \mathrm{ml}$ Fluorisil particles diameter 150/200 $\mu \mathrm{m}$, Supelco).

At the end of the purification samples were concentrated using the centrifugal evaporator to a final volume of about $1 \mathrm{ml}$, checked by weighing. To each sample $10 \mu \mathrm{l}$ of an injection standard (MBP-CP solution/mixture of PCB77, PCB81, PCB126 and PCB169, conc. $10 \mu \mathrm{g} \mathrm{ml}^{-1}$; Wellington Laboratories) was added before being injected into the gas chromatograph. A gas chromatograph mod. 5890A (Agilent, USA), equipped with a PTV injection system mod. 6890, and coupled with a mass spectrometric detector mod. 5973A (Agilent, USA) operating both in SIM (Selected Ion Monitoring) and TIC (Total Ion Current) modes, was used for the determination of PAHs.

In both cases, chromatographic separation was performed on a fused silica capillary column MS-5 (Hewlett Packard Italiana) 95\% dimethyl-5\% phenyl polysiloxane chemically bonded stationary phase, $0.25 \mathrm{~mm}$ internal diameter, $0.25 \mu \mathrm{m}$ film thickness, $30 \mathrm{~m}$ length; the column was connected to a $2 \mathrm{~m}$ long $0.32 \mathrm{~mm}$ internal diameter deactivated fused silica capillary pre-column. The temperature profile of the chromatographic oven was the following: initial temperature, $50^{\circ} \mathrm{C}$, isothermal for $5 \mathrm{~min}$; $15^{\circ} \mathrm{C} \min ^{-1}$ up to $150{ }^{\circ} \mathrm{C}$ and isothermal for $1 \mathrm{~min}, 5^{\circ} \mathrm{C} \min ^{-1}$ up to $240^{\circ} \mathrm{C}, 25^{\circ} \mathrm{C} \min ^{-1}$ up to $300^{\circ} \mathrm{C}$ and isothermal for $5 \mathrm{~min}$. In order to perform large sample volume injections, 
the injection system, equipped with a deactivated glass wool packed insert and with the split valve open, was kept at $55^{\circ} \mathrm{C}$ during the initial $30 \mathrm{~s}$, then the split valve was closed and the injector heated at $500^{\circ} \mathrm{C} \min ^{-1}$ up to $280^{\circ} \mathrm{C}$.

Helium $99.995 \%$ purity (Rivoira, Italy) was used as a carrier gas at constant flow (1 ml $\min ^{-1}$ ) and $90 \mathrm{kPa}$ at initial temperature. The sample volume injected was $40 \mu \mathrm{l}$, unless otherwise specified.

Set-up of bacterial cultures. For the initial enrichment, biphenyl (BP) served as the sole carbon and energy source for growth, as follows. Aliquots $(1 \mathrm{ml})$ of a stock solution (75 $\mathrm{mg} \mathrm{ml}^{-1}$ ) of BP dissolved in chloroform was added to empty Erlenmeyer flasks and the solvent was allowed to evaporate. Then, $75 \mathrm{ml}$ of each seawater sample was added to BP containing flasks (final concentration $0.1 \%$, wt/vol). In the case of sediment, $10 \mathrm{~g}$ of wet samples were used to inoculate $75 \mathrm{ml}$ of filter-sterilized seawater (collected from the same site at sampling time) in BP containing flasks (final concentration $0.1 \%$, wt/vol). An additional culture flask was set up for each sample with no added carbon source to serve as a negative control. Three successive enrichments were prepared in Bushnell Haas (BH; Difco) minimal medium amended with $3 \%$ (wt/vol) $\mathrm{NaCl}(\mathrm{BH}$ plus $\mathrm{NaCl}$ ) by using $10 \%(\mathrm{wt} / \mathrm{vol})$ culture fluid used as the inoculum for each subculture at 3-week intervals. All cultures were incubated aerobically at $4^{\circ} \mathrm{C}$ with shaking at $175 \mathrm{rpm}$.

Bacterial isolation. Aliquots $(100 \mu \mathrm{l})$ of the last two enrichments were plated on solidified $\mathrm{BH}$ plus $\mathrm{NaCl}$ (containing agar; $1.5 \%$, wt/vol). BP was added as crystals in the Petri dish lid after inoculation. Replicate plates were incubated at $4^{\circ} \mathrm{C}$ for 30 days. $\mathrm{BH}$ 
plus $\mathrm{NaCl}$ agar plates without $\mathrm{BP}$ were used as a control. For bacterial isolation, colonies were randomly selected from agar plates, picked and subcultured three times under the same conditions. Isolates were named with the station name and matrix (W and $\mathrm{S}$ for water and sediment, respectively) followed by the isolation number (e.g., C1W-9 was the isolate 9 from water collected at station $\mathrm{C} 1$ ).

Bacterial growth in the presence of Aroclor 1242. Bacterial growth in the presence of PCBs was tested in liquid $\mathrm{BH}$ plus $\mathrm{NaCl}$. Aroclor 1242 (Sigma-Aldrich; 100 ppm in dichloromethane) was added as sole carbon and energy source (final concentration $0.1 \%$, wt/vol) (Michaud et al., 2007). Aroclor 1242 is a mixture of PCB congeners (ranging from dichloro- to hexachlorobiphenyls) made of twelve carbon atoms in the biphenyl molecule and containing $42 \%$ chlorine by weight (Frame et al., 1996). Cultures were incubated in duplicates at $4{ }^{\circ} \mathrm{C}$ for one month. The ability to use PCBs as growth substrates was evaluated according to the degree of turbidity or the appearance of cellular flocs in the test tubes. Uninoculated medium was incubated in parallel as a negative control.

$16 S$ rRNA gene amplification. Bacterial isolates able to grow in the with PCBs as the sole carbon source were identified by the $16 \mathrm{~S}$ rRNA gene sequencing. Single colonies of each strain were lysed by heating at $95^{\circ} \mathrm{C}$ for $10 \mathrm{~min}$. Amplification of $16 \mathrm{~S}$ rRNA gene was performed with a thermocycler (Mastercycler GeneAmp PCR-System 9700, Applied Biosystem, USA) using Bacteria-specific primers 27F (5'AGAGTtTGATC(AC)TGGCTCAG-3') and 1492R (5'- 
TACGGYTACCTTGTTACGAC-3'). The reaction mixtures were assembled at $0^{\circ} \mathrm{C}$ and contained $1 \mu \mathrm{l}$ DNA, $0.4 \mu \mathrm{l}$ of each of the two primers $(10 \mu \mathrm{M}), 0.4 \mu \mathrm{l}$ of each $\mathrm{dNTP}(10$ $\mathrm{mM}), 2 \mu \mathrm{l}$ of reaction buffer $10 \mathrm{X}, 0.4 \mu \mathrm{l}$ of BSA $\left(3 \mathrm{mg} \mathrm{ml}^{-1}\right), 0.2 \mu \mathrm{l}$ of Taq polymerase 5 PRIME $\left(5 \mathrm{U}_{\mu 1}^{-1}\right)$, and sterile Milli-Q water to a final volume of $20 \mu \mathrm{l}$. Negative controls for DNA extraction and PCR setup (reaction mixture without a DNA template) were also used in every PCR run. The PCR program was as follows: 1) $95^{\circ} \mathrm{C}$ for $1.30 \mathrm{~min}$; 2) 5 cycles at $95^{\circ} \mathrm{C}$ for $30 \mathrm{~s}, 60^{\circ} \mathrm{C}$ for 30 se and $72^{\circ} \mathrm{C}$ for $\left.4 \mathrm{~min} ; 3\right) 5$ cycles at $95^{\circ} \mathrm{C}$ for $30 \mathrm{~s}$, $55^{\circ} \mathrm{C}$ for $30 \mathrm{~s}$ and $72^{\circ} \mathrm{C}$ for $4 \mathrm{~min}$; 4) 25 cycles at $95^{\circ} \mathrm{C}$ for $30 \mathrm{~s}, 50^{\circ} \mathrm{C}$ for $30 \mathrm{~s}$ and $72^{\circ} \mathrm{C}$ for $4 \mathrm{~min}$; 5) $72^{\circ} \mathrm{C}$ for $10 \mathrm{~min}$; 6) $60^{\circ} \mathrm{C}$ for $10 \mathrm{~min}$ (Michaud et al., 2007). The results of the amplification reactions were analyzed by agarose gel electrophoresis $(1 \%, \mathrm{wt} / \mathrm{vol})$ in TAE buffer (0.04 M Tris-acetate, $0.02 \mathrm{M}$ acetic acid, 0.001 M EDTA), containing $1 \mu \mathrm{g}$ $\mathrm{ml}^{-1}$ of ethidium bromide.

Sequencing and analysis of 16S rRNA genes. Amplified products were purified using the QIAquick PCR purification kit (Qiagen), following the manufacturer instructions. Sequencing was carried out at the Macrogen Laboratory (The Netherland). Next relatives of isolates were determined by comparison to $16 \mathrm{~S}$ rRNA gene sequences in the NCBI GenBank and the EMBL databases using BLAST, and the "Seqmatch" and "Classifier" programs of the Ribosomal Database Project II (http://rdp.cme.msu.edu/) (Altschul et al., 1997).

Sequences were further aligned using the program Clustal W (Thompson et al., 1994) to the most similar orthologous sequences retrieved from database. Each alignment was checked manually, corrected and then analyzed using the Neighbour-Joining method 
(Saitou and Nei, 1987) according to the model of Jukes-Cantor distances. A phylogenetic tree was constructed using the MEGA 5.2 (Molecular Evolutionary Genetics Analysis) software (Kumar et al., 2004). The robustness of the inferred trees was evaluated by 400 bootstrap re-samplings.

Screening for the $\boldsymbol{b p h} \mathbf{A}$ gene. Strains showing the ability to grow in the presence of Aroclor 1242 as the sole carbon and energy source were screened for the presence of the catabolic gene $b p h \mathrm{~A}$ involved in PCB degradation. The presence of genes was determined by PCR, using specific primers: 2BPHFWD1 (5' ADVCCSCGBGCCGCBTCHTCG $\left.\quad 3^{\prime}\right)$ and 2BPHREV1 ADVCCSCGBGCCGCBTCHTCG 3') (Master and Mohn, 2001). The reaction mixture was assembled at $0^{\circ} \mathrm{C}$ and contained $1 \mu \mathrm{DNA}, 1 \mu \mathrm{l}$ of each of the two primers $(10 \mu \mathrm{M})$, $0.4 \mu 1$ of each $\mathrm{dNTP}(10 \mathrm{mM}), 2 \mu 1$ of reaction buffer 10X, $0.4 \mu 1$ of BSA (2.5\%), $0.4 \mu 1$

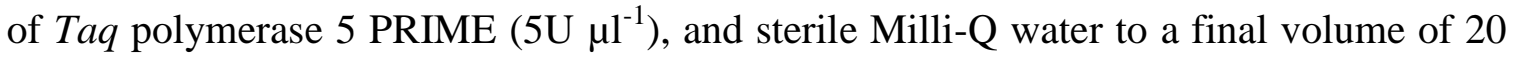
$\mu 1$. Negative controls for DNA extraction and PCR setup (reaction mixture without a DNA template) were also used in every PCR run, DNA from Burkholderia xenovorans (DSM17367) was used as positive control. The PCR program was as follows: 1) $95^{\circ} \mathrm{C}$ for $5 \mathrm{~min}$; 2) 35 cycles at $94^{\circ} \mathrm{C}$ for $45 \mathrm{~s}, 58^{\circ} \mathrm{C}$ for $1 \mathrm{~min}$ and $72^{\circ} \mathrm{C}$ for $2 \mathrm{~min}$; 3) $72^{\circ} \mathrm{C}$ for 10 min (Lehtinen et al., 2013). The results of the amplification reactions were analyzed by agarose gel electrophoresis $(2 \%, \mathrm{wt} / \mathrm{vol})$ in TAE buffer $(0.04 \mathrm{M}$ Tris-acetate, $0.02 \mathrm{M}$ acetic acid, $0.001 \mathrm{M}$ EDTA), containing $1 \mu \mathrm{g} \mathrm{ml}^{-1}$ of ethidium bromide and the fragment size was evaluated through the use of a $1 \mathrm{~kb}$ ladder (Fermentas). 
Biodegradation efficiency. The biodegradation efficiency on Aroclor 1242 was assayed for selected isolates, as described by Michaud et al. (2007), with few modifications. Isolates were grown in $200 \mathrm{ml}$ of Aroclor 1242 (1\%) supplemented BH, as described earlier, and incubated at 4 and $15^{\circ} \mathrm{C}$ in duplicates for one month. Uninoculated controls were incubated in parallel to monitor abiotic losses of the substrates. After incubation, the biodegradation activity was stopped by acidifying cultures with $\mathrm{HCl} 10 \mathrm{M}$ to achieve $\mathrm{pH}$ 2. Cultures were centrifuged at $8000 \mathrm{rpm}$ for $20 \mathrm{~min}$ at $4^{\circ} \mathrm{C}$ to remove cellular material, and extracted in duplicates, as follows. Before PCB extraction, $10 \mu \mathrm{l}$ of octachloronaphthalene $(\mathrm{OCN})$ solution $\left(5 \mathrm{mg} \mathrm{ml}^{-1}\right.$ in $\left.\mathrm{CH}_{2} \mathrm{Cl}_{2}\right)$ was added to each aliquot to monitor substrate losses during the extraction procedure. Cultures were extracted three times with $10 \mathrm{ml}$ of $\mathrm{CH}_{2} \mathrm{Cl}_{2}$ in a separatory funnels to isolate the organochlorine molecules from the enrichment cultures. Funnels were vigorously shaken for $15 \mathrm{~min}$ during each extraction. The three organic phases were pooled and the solvent evaporated to dryness.

The composition of PCBs and their concentration were determined by high resolution gas chromatography-mass spectrometry (GC-MS) using a Perkin-Elmer TurboMS AutoSystem XL GC, equipped with a DB-TPH capillary column (30 m with a $0.322 \mathrm{~mm}$ i.d. and $0.25 \mu \mathrm{m}$ film thickness, J \& W Scientific). Helium (5 bar) was used as carrier gas $\left(1.8 \mathrm{ml} \mathrm{min}^{-1}\right)$. The injector was kept at $300^{\circ} \mathrm{C}$; the column oven was initially kept at a temperature of $200^{\circ} \mathrm{C}$ for $4 \mathrm{~min}$, and then heated up to $300^{\circ} \mathrm{C}$ at a rate of $8{ }^{\circ} \mathrm{C} \mathrm{min}^{-1}$. Two$\mu \mathrm{l}$ portion of each sample, containing $79.3 \mathrm{ng}$ of heptamethyl nonane as internal standard (to account for injection errors and other variable encountered during the 
chromatographic analysis), was analyzed by means of the splitless injection technique (50 $\mathrm{ml} \mathrm{min}{ }^{-1}$ ). Finally, the percentage reduction of Aroclor was determined according to the following equation:

$\% \mathrm{R}=100-\left[\left(\mathrm{H}_{\mathrm{PCB} \text { sample }} / \mathrm{H}_{\mathrm{PCB} \text { control }}\right) \mathrm{X} 100\right]$

where $\mathrm{H}_{\mathrm{PCB}}$ sample and ${ }_{\mathrm{HPCB}}$ control are the height of a PCB peak in the sample and the control, respectively.

Nucleotide sequence accession numbers. Nucleotide sequences have been deposited in the NCBI GenBank database under the accession numbers KX000002-KX000046.

\section{RESULTS}

PCB concentration in natural samples. Chemical analyses were carried out for both water and sediment samples. These latter did not show significant results, probably due to their granulometry, rich in sand and pebbles. Overall, higher concentrations of PCBs were observed in the water from the stations A, B (both next to the glacier; 27.69 and $23.16 \mathrm{pg}^{-1}$, respectively), and $\mathrm{E}$ (next to the open sea; $19.04 \mathrm{pg}^{-1}$ ). A total of nine PCB congeners were detected (listed in Table 2) at concentrations that ranged between 0.13 [PCB $201\left(2,2^{\prime}, 3,3^{\prime}, 4,5^{\prime}, 6,6^{\prime}\right.$ octachlorobiphenyl) at station C1] and $13.2 \mathrm{pg}^{-1}$ [PCB 138 $\left(2,2,3,4,4^{\prime}, 5^{\prime}\right.$-hexachlorobiphenyl) at station B]. The concentration of PCB congeners was generally below $10 \mathrm{pg} \mathrm{l}^{-1}$. Exceptions were PCB 77 (3,3',4,4'-tetrachlorobiphenyl) and PCB 138 at station A (11.67 and $10.31 \mathrm{pg} \mathrm{l}^{-1}$, respectively), PCB 77 at station E (11 pg l$\left.{ }^{1}\right)$, and PCB 138 at station B (13.2 $\left.\mathrm{pg} \mathrm{l}^{-1}\right)$. 
Isolation and phylogenetic identification of PCB-oxidizing bacterial strains. A total of 246 isolates (116 and 130 from water and sediment samples, respectively) were obtained from BP amended agar plates (Table 3). Among these, 45 isolates $(18.3 \% ; 17$ from water and 28 from sediment, respectively) were able to grow in the presence of Aroclor 1242 as sole carbon source at $4^{\circ} \mathrm{C}$. Bacteria growing on Aroclor 1242 were seldom isolated only from sediment (sites A, B and D) or seawater (site C3). Their affiliation is reported in the Table 4 and Fig. 2. Comparative sequence analysis indicated that the majority of isolates were closely related to already known and/or previously isolated bacteria (16S rRNA similarity, $\geq 97 \%$ ). PCB-oxidizing bacterial isolates mainly belonged to the Actinobacteria (eight and ten from water and sediment samples, respectively), followed by the Gammaproteobacteria (six and seven from water and sediment samples, respectively), CF group of Bacteroidetes (four and six from water and sediment samples, respectively), and Firmicutes (four isolates).

A total of 16 phylotypes were obtained. All sequences with similarity $\geq 97 \%$ were considered to represent one phylotype and were grouped into Operational Taxonomic Units (OTUs). These were generally shared between different stations and/or matrix (sediment and water), whereas few OTUs were retrieved from single samples or matrices (Table 4). It was the case of OTU 4 (retrieved only in water at station E, EW), OTU 5 (members were isolated only from water at stations $\mathrm{C} 1$ and $\mathrm{C} 3, \mathrm{C} 1 \mathrm{~W}$ and $\mathrm{C} 3 \mathrm{~W}$ ), OTUs 6 and 7 were retrieved only from sediment at stations B and A, respectively (BS and AS, respectively).

As it is shown in the Figure 2, the 18 Actinobacteria (four phylotypes) clustered in two main branches: the first one was composed by a single isolate (i.e., AS-7) which was 
strongly related to the genus Nocardioides, whereas the second branch included members in the genera Salinibacterium (13 isolates within two groups) and Microbacterium (four isolates within the OTU 2). All the Firmicutes (four isolates) clustered in a single OTU (OTU 7) and were strongly related to the genus Planococcus.

Among Gram-negative isolates, the Proteobacteria clustered into the Gamma- and Alphaproteobacteria. The latter were represented by a single isolate, DS-1, closely related to Devosia sp. The Gammaproteobacteria contained five different phylotypes clustering in two main branches, which were represented by Pseudomonas spp. (11 isolates in four groups) and Marinobacter spp. (a single isolate, CS2-8B). The five phylotypes within the CF group of Bacteroidetes formed two distinct clusters: the first one included the genus Algoriphagus (two isolates within the OTU 4), while the second cluster branched in two sub-clusters that included the genera Gelidibacter (isolate DS-10) and Bizionia (four isolates within the OTU 6), and the genera Aequorivita spp. (OTU 5 and isolate $\mathrm{C} 2 \mathrm{~S}-1$ ), respectively.

Screening for bph A gene. A total of 17 isolates (out of 45 PCB-oxidizing isolates; seven and ten from water and sediment, respectively) harbored the $b p h \mathrm{~A}$ gene fragment as a 947 bp amplicon was obtained (Figure S1). They belonged to the genera Pseudomonas (isolates C1W-5, C1W-9, C1W-16, BS-23, C1S-1, C1S-20, and C1S-21A), Algoriphagus (isolates EW-10A and EW-10C), Bizionia (isolate BS-8B), Salinibacterium (isolates ES-1, C1S-23B, C3W-3 and BS-14B), Leifsonia (isolate C1S22B), Microbacterium (isolate C3W-24A), and Devosia (isolate DS-1). 
Biodegradation efficiency. Based on obtained results, eight strains among those showing the $b p h \mathrm{~A}$ gene fragment were selected for assaying their biodegradation efficiency on Aroclor 1242, as follows: Devosia sp. DS-1 (among the Alphaproteobacteria), Pseudomonas sp. C1W-9 (among the Gammaproteobacteria), Algoriphagus sp. EW-10A and Bizionia sp. BS-8B (among the CF group of Bacteroidetes), Microbacterium sp. C3W-24A, Salinibacterium spp. C3W-3, C1S-22B and ES-1 (among the Actinobacteria). In addition, Gelidibacter sp. DS-10 was randomly chosen among those strains that were able to grow in the presence of Aroclor 1242, but did not show the bphA gene fragment. All results from bacterial cultures were normalized to the abiotic loss level recorded in the control (between 20 and 30\% for each). With few exceptions, tested strains showed greater efficiency at $15^{\circ} \mathrm{C}$ (range $3.5-43.3 \%$ ) than at $4^{\circ} \mathrm{C}$ (range 7.4-67.9\%) (Figure 3). Degradation of individual congeners was estimated (Table 5). Isolates were able to reduce most chromatographic peaks by more than $50 \%$, with some di- and trichlorobiphenyls that were quite totally removed (>90\%). At this regard, Pseudomonas sp. C1W-9, Devosia sp. DS-1, Salinibacterium spp. ES-1 and C3W-3, and Gelidibacter sp. DS-10 were particularly efficient at $15^{\circ} \mathrm{C}$, while Salinibacterium sp. C1S-22B and Microbacterium sp. C3W-24A at $4^{\circ} \mathrm{C}$. Finally, tetrachlorobiphenyls were generally more significantly removed at 4 than at $15^{\circ} \mathrm{C}$.

\section{DISCUSSION}

This work was mainly focused on the isolation and biodegradation potential on PCBs by cultivable psychrotolerant bacteria isolated from an Arctic coastal environment. A 
preliminary survey was carried out by GC-MS to evaluate the level of PCB pollution in the analyzed matrices (seawater and sediment). PCBs have been often detected in the Arctic. The presence in the basin (thousands of kilometers distant from industrial centers) of POPs confirms that these compounds are transported over vast distances with air masses and deposited in regions devoid of any human pressure. The Arctic, regarded in the past as a pristine area in terms of anthropogenic pollution, has nowadays become an area of great concern. Previous studies have demonstrated that this region is a significant recipient of various groups of persistent toxic substances originating from countries in both the Northern and Southern Hemispheres [Jiao, 2009]. PCBs have been determined far more frequently in samples from the Arctic, e.g., in lake sediments (Svalbard, Bjørnøya, Canadian Arctic, Russia, Greenland) [Jiao. 2009], [Cecinato, A.; Mabilia, R.; Marino, F. Relevant organic components in ambient particulate matter, collected at Svalbard Islands (Norway). Atmos. Environ. 2000, 34, 5061-5066] [Wang, Z.; Ma, X.; Na, G.; Lin, Z.; Ding, Q.; Yao, Z. Correlations between physicochemical properties of PAHs and their distribution in soil, moss and reindeer dung at Ny-Ålesund of the Arctic. Environ. Pollut. 2009, 157, 3132-3136]

[Evenset, A.; Christensen, G.N.; Skotvold, T.; Fjeld, E.; Schlabach, M.; Wartena, E.; Gregor, D. A comparison of organic contaminants in two Arctic lake ecosystems, Bjornoya (Bear Island), Norway. Sci. Total Environ. 2004, 318, 125-141.]

[Evenset, A.; Christensen, G.N.; Carroll, J.; Zaborska, A.; Berger, U.; Herzke, D.; Gregor, D., Historical trends in persistent organic pollutants and metals recorded in sediment from Lake Ellasjoen, Bjornoya, Norwegian Arctic. Environ. Pollut. 2007, 146, 196-205.] 
[Rawn, D.F.K.; Lockhart, W.L.; Wilkinson, P.; Savoie, D.A.; Rosenberg, G.B.; Muir, D.C.G., Historical contamination of Yukon Lake sediments by PCBs and organochlorine pesticides: Influence of local sources and watershed characteristics. Sci. Total Environ. 2001, 280, 17-37.]

[Stern, G.A.; Braekevelt, E.; Helm, P.A.; Bidleman, T.F.; Outridge, P.M.; Lockhart, W.L.;McNeeley, R.; Rosenberg, B.; Ikonomou, M.G.; Hamilton, P.; Tomy, G.T.; Wilkinson, P. Modern and historical fluxes of halogenated organic contaminants to a lake in the Canadian Arctic, as determined from annually laminated sediment cores. Sci. Total Environ. 2005, 342, 223-243.]

Temporal trends of POPs show increasing concentrations or a tendency to leveling off depending on the matrix (seawater or sediment) and location, but no uniform picture for the Arctic emerges (Giannarelli S., unpublished data; Garmash et al., 2013). The harbor area was characterized by a prevalent presence of PAHs (data not shown), likely due to local pollution and fossil fuel power station (site C). As it was expected, that at station D POPs were generally lower in concentration and their trends were probably affected only by the sea temperature profile. At sites A and B, the highest PCB levels were recorded, accordingly to the high sedimentation flows and sea currents. Moreover, at the station A, the dilution was balanced by a high concentration of pollutants due to their release from sediments. Overall, results from the chemical analyses confirm previous observations and highlight a higher pollution level in seawater collected from the stations A and B. This finding could be dependent on the release in the fjord of PCBs that, once reached the Svalbard Archipelago by long-range transport during winter, have accumulated in the Kongsvegen glacier ice and snow cover, which melt during summer time. Sea ice, one of 
the defining characteristics of the Arctic, is usually ignored as a potential transport medium. Unique to the Arctic are the large amounts of fine grained particulate material incorporated in and transported by sea ice formed on the shelves. Many pollutants tend to sorb onto fine-grained particles and/or organic material, and may therefore be attached to the particles incorporated into the ice. During several years of transport, pollutants concentrated in the oceanic surface microlayer may also be incorporated in drifting ice, while pollutants deposited from the atmosphere accumulate on the snow and ice surface. Drifting sea ice in the Arctic may transport contaminants from coastal areas across the pole and release them during melting far from the source areas. Arctic sea ice often contains sediments entrained on the Siberian shelves and receives atmospheric deposition from Arctic haze. Elevated levels of some heavy metals (e.g. lead, iron, copper and cadmium) and organochlorines (e.g. PCBs and DDTs) have been observed in ice sampled in the Siberian seas, north of Svalbard, and in Baffin Bay. In order to determine the relative importance of sea ice transport in comparison with air/sea and oceanic processes, more data is required on pollutant entrainment and distribution in the Arctic ice pack.

A quite high PCB level was also measured at station E. In this case, this result could be due an accumulation process strictly linked to the water circulation inside the fjord. The high concentration of PCB77 (3,3,4,4-tetrachlorobiphenyl), PCB 138 (2,2,3,4,4,5hexachlorobiphenyl) and PCB 201 (2,2',3,3',4,5',6,6'-octachlorobiphenyl) is not surprising as they constitute a considerable amount in different Aroclor mixtures. In particular, tetra-CBs could account for the $30 \%$ of Aroclor 1242, while esa-CBs and epta-CBs are the major representative compounds in Aroclor 1254 and 1260, respectively. 
The biodegradation of PCBs at low temperature conditions is of great importance due to the increasing vulnerability of cold habitats to increasing levels of these persistent pollutants (Bajaj and Singh, 2015). PCB-mineralizing psychrotolerant bacteria have been previously isolated from Antarctic marine habitats (Yakimov et al., 1999; De Domenico et al., 2004; Michaud et al., 2007; Lo Giudice et al., 2013) and cold Arctic soils (Mohn et al., 1997; Master and Mohn, 1998). Conversely, to the best of our knowledge, the enrichment, isolation and phylogenetic characterization of PCB-degrading bacteria from Arctic marine environment, such as the Kongsfjorden, is here reported for the first time. The results obtained from the present study contribute to the understanding on PCB biodegradation potential of bacteria from cold environments. Each of the 246 bacterial isolates analyzed in this work was examined for its ability to grow in the presence of the PCB mixture Aroclor 1242. Overall, 18.3\% of isolates (45 isolates) gave a positive result, with percentage of positive bacteria in water samples being higher than those reported for Antarctic seawater (14.7 vs $7.1 \%$ of total isolates from seawater; Michaud et al., 2007). Conversely, the percentage of PCB-oxidizing isolates from Arctic sediment was comparable to that observed in Antarctica (21.5 vs $21.4 \%$ of total isolates from sediment; Lo Giudice et al., 2013). In addition, PCB degraders were isolated from all sampling stations suggesting that these microorganisms could be well distributed along Kongsfjorden, including less PCB-contaminated sites.

PCB-oxidizing isolates mainly belonged to bacterial phyla that have been previously reported for the Kongsfjorden using both culture-independent and culture-dependent approaches (Tian et al., 2009; Zeng et al., 2013; Prasad et al., 2014), and are typically found in the marine environment. This is particularly true for the Gammaproteobacteria 
constituting a large phylogenetic group of cosmopolitan species which are generally well represented within the marine bacterioplankton communities (Lo Giudice et al., 2012). Contrary to the Gammaproteobacteria, the Actinobacteria and Firmicutes are generally thought to be associated with soil and sediment habitats (Peeters and Willems, 2011), while members of the CF group of Bacteroidetes are mainly associated with sea-ice, as well as with glacier snow and ice. As sampling was performed during summer, it is plausible to assume the origin of Bacteroidetes from the sea-ice and glacier compartments.

The enrichment procedure allowed us selecting members in bacterial genera that have been previously detected in polluted environments and/or are well known PCB degraders (e.g. Pseudomonas spp.), even if their biodegradation potential has been rarely estimated (Gibson et al., 1993; De et al., 2006). An innovative aspect of the present research was the isolation of bacterial strains belonging to genera (e.g. Algoriphagus, Devosia and Salinibacterium) that have been never reported as able to utilize PCBs as the sole carbon source. In fact, as far we know, among psychrotolerant bacteria able to degrade commercial mixtures of PCBs only Pseudomonas (Mohn et al., 1997; Master and Mohn, 1998), Rhodococcus (De Domenico et al., 2004), Hydrogenophaga (Lambo and Patel, 2006a-b; Lambo and Patel, 2007), Pseudoalteromonas, Psychrobacter and Arthrobacter (Michaud et al., 2007) closely related strains have been reported to date (Lo Giudice et al., 2010).

To confirm the biodegradation capability of our isolates, analyses were carried out at genetic level. The bph gene is organized as an operon that presents, in the order, bphAlA2A3A4-bphB-bphC-bphD. This internal organization is maintained essentially 
identical in many strains, although it can have deletions of some parts (Hayase et al., 1990), or different internal reorganization. For example, in Rhodococcus sp. RHA1 genes bph are sorted differently and are plasmid-harbored (Masai et al., 1995; Takeda et al., 2004). There are also microorganisms with gene cluster $b p h$ dissimilar, for organization, number of genes and sequences (Peloquin and Greer, 1993; Arai et al., 1998; Mouz et al., 1999). The bphA gene portion encodes for the first fundamental step in the biphenyl upper pathway, in which biphenyl is converted to dihydrodiol and further to CBA. The presence of the bacterial $b p h$ A gene, confirming the ability to aerobically degrade PCBs, was tested by PCR with a previously published primer set (Master and Mohn, 2001). Interestingly, the $b p h \mathrm{~A}$ gene was detected in a large number of isolates (17 out of 45 ; $37.8 \%$ ), thus indicating the strong capability of indigenous bacterial populations to aerobically degrade PCBs in seawater and sediment of the Kongsfjorden. However, the real number of isolates showing the $b p h \mathrm{~A}$ gene was probably underestimated, as little is known about the total coverage of even the degenerated primers that were used. This hypothesis is supported by the high biodegradation potential showed by Gelidibacter sp. DS-10, even if it did not seem to possess the gene, and by the lack of the gene in all the isolates belonging to the same OTU (i.e., OTUs 1, 2, 3 and 6). It is well known that genes for catabolic functions have adaptively evolved in nature by various genetic events (e.g. mutation, recombination, gene transfer, and assembly), resulting in a family of diverse but highly related sequences (Furukawa et al., 2004). Considering these facts we could assume that a gene or cluster of genes coding enzymes responsible for the PCB degradation activity is probably plasmid-harbored or present on transposons (Furukawa et 
al., 2004). Further analyses will be needed to elucidate the relation between the occurrence of the $b p h \mathrm{~A}$ gene and the biodegradation ability of our bacterial isolates.

The biodegradation potential on Aroclor 1242 was evaluated for eight $b p h$ A-harboring isolates, which were selected based on their phylogenetic affiliation, and Gelidibacter sp. DS-10. The lower incubation temperature tested $\left(4^{\circ} \mathrm{C}\right)$ did not seem to severely hamper the degradation process, although the highest efficiencies were generally obtained at $15^{\circ} \mathrm{C}$. This finding is in line with data previously reported for other psychrotolerant bacteria (Master and Mohn, 1998; Michaud et al., 2007). Exceptions were Salinibacterium sp. C1S-22B and Microbacterium sp. C3W-24A that better degraded Aroclor 1242 at $4^{\circ} \mathrm{C}$, and Bizionia sp. BS-8B that showed similar biodegradation patterns when growing at 4 and $15^{\circ} \mathrm{C}$. This finding could be related to the temperature dependence of $b p h \mathrm{~A}$ induction in our isolates, as previously observed by other authors (Master and Mohn, 2001), suggesting that physical environmental conditions can affect bph A expression in PCB-degrading bacteria and indicating a stronger cold adaptation of Salinibacterium sp. C1S-22B and Microbacterium sp. C3W-24A.

The degradation capability at temperatures that are close to the in situ seawater temperature suggests that the microbial community along the Kongsfjorden possess a catabolic potential for PCB degradation that could occur under in situ environmental conditions.

In accordance to Lambo and Patel (2006b), the different congeners in Aroclor 1242 were differently removed at 4 and $15^{\circ} \mathrm{C}$, with di- and trichlorobiphenyls that were better utilized at $15^{\circ} \mathrm{C}$, and the degradation of tetrachlorobiphenyls that was generally slowed down at $4^{\circ} \mathrm{C}$. This finding suggests that the incubation temperature could be a major 
determining factor in the biodegradation process and that specificity of cells for some congeners was probably different at different temperatures (Lambo and Patel, 2006b; Michaud et al., 2007).

Results obtained on the removal patterns of individual PCB congeners also indicate that the biodegradative potential could be related to the phylogenetic affiliation of the isolates. Differences were also observed among isolates belonging to the same genus, i.e. Salinibacterium. However, further analyses are needed to establish if the biodegradation ability is species- or strain-specific.

This study is a contribution to the still poor knowledge on psychrotolerant PCBdegrading bacteria. Pollutant removal from vulnerable and extremely cold systems is of vital importance, as bioremediation is now accepted as a practicable approach to eliminate POPs from the environment (Bajaj and Singh, 2015; Fuentes et al., 2010). Obtained results suggest that psychrotolerant microorganisms may be exploited for the decontamination of polluted cold sites, thanks to their efficient survival strategies, including enzymes that are active at low temperatures, their ability to cope with in situ environmental conditions and their high biotechnological potential. This could lead to remediation approaches that may be more economical- and environmental-friendly than conventional methods.

\section{ACKNOWLEDGEMENTS}

A. Lo Giudice, S. Giannarelli and S. Francesconi wish to thank Dr. Nick Cox for valuable support in organizing their stay in Ny-Alesund and the NERC Station for lab facilities. We have no competing interests to declare. 
Maria Papale built the phylogenetic tree and performed much of the computational analysis for the manuscript and assisted in constructing the figures and writing drafts of the manuscript. Stefania Giannarelli and Sandro Francesconi performed sample collection and chemical analyses on environmental matrices, and assisted in interpretation of the data. Gaetano Di Marco performed GC-MS on bacterial culture for the estimation of bacteria biodegradation efficiency. Carmen Rizzo and Emilio De Domenico assisted in interpretation of the data. Anu Mikkonnen assisted in biomolecular analyses, interpretation of the data, and useful discussions on the manuscript. Luigi Michaud and Angelina Lo Giudice designed and supervised the overall approach.

\section{FUNDING INFORMATION}

This research was supported by grants from the ARCFAC V (Grant n. ARCFAC-0261292008-70), research project "Occurrence of PCB-degrading bacteria in relation to PCB contamination in coastal marine environments in Ny-Ålesund (Svalbard, Spitsbergen) (PolyArc).

\section{REFERENCES}

Altschul, S.F., Madden, T.L., Schaffer, A.A., Zhang, J., Zhang, Z., Miller, W., Lipman, D.J., 1997. Gapped BLAST and PSI-BLAST: A new generation of protein database search programs. Nucleic Acids Res. 25, 3389-3402.

Arai, H., Kosono, S., Taguchi, K., Maeda, M., Song, E., Fuji, F., Chung, S.Y., Kudo, T., 1998. Two sets of biphenyl and PCB degradation genes on a linear plasmid in Rhodococcus erythropolis TA421. J. Biosci. Bioeng. 86, 595-599. 
Bajaj, S., Singh, D.K., 2015. Biodegradation of persistent organic pollutants in soil, water and pristine sites by cold-adapted microorganisms: mini review. Int. Biodeter. Biodegr. 100, 98-105.

Bengtson Nash, S., 2011. Persistent organic pollutants in Antarctica: current and future research priorities. J. Environ. Monitor. 13, 497-504

Ceccarini, S., Giannarelli, S., 2007. Polychlorobiphenyls. In: Nollett, L.M.L., De Gelder, L.S.P. (Eds.), Handbook of Water Analysis, CRC Press, Taylor \& Francis Group, Boca Raton, FL, 20, p. 529-562.

Cecinato, A., Mabilia, R., Marino, F., 2000. Relevant organic components in ambient particulate matter, collected at Svalbard Islands (Norway). Atmosph. Environ. 34, 50615066.

De, J., Ramaiah, N., Sarkar, A., 2006. Aerobic degradation of highly chlorinated polychlorobiphenyls by a marine bacterium, Pseudomonas $\mathrm{CH} 07$. World J. Microbiol. Biotechnol. 22, 1321-1327.

De Domenico, M., Lo Giudice, A., Michaud, L., Saitta, M., Bruni, V., 2004. Diesel oil and PCB-degrading bacteria isolated from Antarctic seawaters (Terra Nova Bay, Ross Sea). Polar Res. 23, 141-146.

Frame, G.M., Cochran, J.W., Bøwadt, S.S., 1996. Complete PCB congener distributions for 17 Aroclor mixtures determined by 3 HRGC systems optimized for comprehensive, quantitative, congener specific analysis. J. High Resolut. Chrom. 19, 657-668.

Fuentes, M., Benimeli, C., Cuozzo, S., Amoroso, M., 2010. Isolation of pesticidedegrading actinomycetes from a contaminated site: bacterial growth, removal and dechlorination of organochlorine pesticides. Int. Biodeter. Biodegr. 64, 434-441. 
Fuoco, R., Giannarelli, S., Wei, Y., Abete, C., Francesconi, S., Termine, M., 2005. Polychlorobiphenyls and polycyclic aromatic hydrocarbons in the sea-surface micro-layer and the water column at Gerlache Inlet, Antarctica. J. Environ. Monitor. 7, 1313-1319.

Fuoco, R., Capodaglio, G., Muscatello, B., Radaelli, M., 2009. Persistent Organic Pollutants (POPs) in the Antarctic environment-A Review of Findings. Scientific Committee on Antarctic Research (SCAR), Cambridge.

Furukawa, K., Suenaga, H., Goto, M., 2004. Biphenyl dioxygenases: functional versatilities and directed evolution. J. Bacteriol. 186, 5189-5196.

Garmash, O., Hermanson, M.H., Isaksson, E., Schwikowski, M., Divine, D., Teixeira, C., Muir, D.C., 2013. Deposition history of polychlorinated biphenyls to the Lomonosovfonna glacier, Svalbard: A 209 congener analysis. Environ. Sci. Technol. 47, 12064-12072.

Gibson, D.T., Cruden, D.L., Haddock, J.D., Zylstra, G.J., Brand, J.M., 1993. Oxidation of polychlorinated biphenyls by Pseudomonas sp. strain LB400 and Pseudomonas pseudoalcaligenes KF707. J. Bacteriol. 175, 4561-4564.

Gillan, D.C., Danis, B., Pernet, P., Joly, G., Dubois, P., 2005. Structure of sedimentassociated microbial communities along a heavy-metal contamination gradient in the marine environment. Appl. Environ. Microbiol. 71, 679-690.

Hayase, N., Taira, K., Furukawa, K., 1990. Pseudomonas putida KF715 bphABCD operon encoding biphenyl and polychlorinated biphenyl degradation: cloning analysis, and expression in soil bacteria. J. Bacteriol. 172, 1160-1164.

Hop, H., Pearson., T, Hegseth, E.N., Kovacs, K.M., Wiencke, C., Kwasniewski, S., Eiane, K., Mehlum, F., Gulliksen, B., Wlodarska-Kowalczuk, M., Lydersen, C., 
Weslawski, J.M., Cochrane, S., Gabrielsen, G.W., Leakey, R.J.G., Lønne, O.J., Zajaczkowski, M., Falk-Petersen, S., Kendall, M., Wängberg, S., Bischof, K., Voronkov, A.Y., Kovaltchouk, N.A., Wiktor, J., Poltermann, M., di Prisco, G., Papucci, C., Gerland, S., 2002. The marine ecosystem of Kongsfjorden, Svalbard. Polar Res. 21, 167-208.

Ito, H., Kudoh, S., 1997. Characteristics of water in Kongsfjorden, Svalbard. Procariotic National Institute of Polar Research, Symposium of Polar Meteorology and Glaciology $11,211-232$.

Jensen, S., Renberg, L., Reutergardh, L., 1977. Residue analysis of sediment and sewage sludge for organochlorines in the presence of elemental sulfur. Anal. Chem. 49, 316-318. Jiao, L., Zheng, G.J., Minh, T.B., Richardson, B., Chen, L., Zhang, Y., Yeung, L.W., Lam, J.C.W., Yang, X., Lam, P.K.S., Wong, M.H., 2009. Persistent toxic substances in remote lake and coastal sediments from Svalbard, Norwegian Arctic: Levels, sources and fluxes. Environ. Pollut. 157, 1342-1351.

Kim, K.S., Hirai, Y., Kato, M., Urano, K., Masunaga, S., 2004. Detailed PCB congener patterns in incinerator flue gas and commercial PCB formulations (Kanechlor). Chemosphere 55, 539-553.

Kumar, S., Tamura, K., Nei, M., 2004. MEGA3: Integrated software for molecular evolutionary genetics analysis and sequence alignment. Brief Bioinform. 2, 150-163.

Lambo, A., Patel, T., 2006a. Cometabolic degradation of polychlorinated biphenyls at low temperature by psychrotolerant bacterium Hydrogenophaga sp. IA3-A. Curr. Microbiol. 53, 48-52.

Lambo, A., Patel, T., 2006b. Isolation and characterization of a biphenyl-utilizing psychrotrophic bacterium, Hydrogenophaga taeniospiralis IA3-A, that cometabolize 
dichlorobiphenyls and polychlorinated biphenyl congeners in Aroclor 1221. J. Basic Microbiol. 46, 94-107.

Lambo, A., Patel, T., 2007. Biodegradation of polychlorinated biphenyls in Aroclor 1232 and production of metabolites from 2, 4, 4'-trichlorobiphenyl at low temperature by psychrotolerant Hydrogenophaga sp. strain IA3-A. J. Appl. Microbiol. 102, 1318-1329.

Lehtinen, T., Mikkonen, A., Sigfusson, B., Ólafsdóttir, K., Ragnarsdóttir, K.V., Guicharnaud, R., 2013. Bioremediation trial on aged PCB-polluted soils-a bench study in Iceland. Environ. Sci. Pollut. Res. 10, 235-26.

Lo Giudice, A., Bruni, V., Michaud, L., 2010. Potential for microbial biodegradation of polychlorinated biphenyls in Polar environments. In: Bej, A.K., Aislabie, J., Atlas, R.M. (Eds), Polar Microbiology: the Ecology, Diversity and Bioremediation Potential of Microorganisms in Extremely Cold Environments. CRC Press, Taylor and Francis Group, p. 255-275.

Lo Giudice, A., Caruso, C., Mangano, S., Bruni, V., De Domenico, M., Michaud, L., 2012. Marine bacterioplankton diversity and community composition in an Antarctic coastal environment. Microb. Ecol. 63, 210-223.

Lo Giudice, A., Casella, P., Bruni, V., Michaud, L., 2013. Response of bacterial isolates from Antarctic shallow sediments towards heavy metals, antibiotics and polychlorinated biphenyls. Ecotoxicology 22, 240-250.

Masai, E., Yamada, A., Healy, J.M., Hatta, T., Kimbara, K., Fukuda, M., Yano, K., 1995. Characterization of biphenyls catabolic genes of gram-positive polychlorinated biphenyls degrader Rhodococcus sp. strain RHA1. Appl. Environ. Microbiol. 61, 2079-2085. 
Master, E.R., Mohn, W.W., 1998. Psychrotolerant bacteria isolated from Arctic soil that degrade polychlorinated biphenyls at low temperatures. Appl. Environ. Microbiol. 64, 4823-4829.

Master, E.R., Mohn, W.W., 2001. Induction of bphA, encoding biphenyl dioxygenase, in two polychlorinated biphenyl-degrading bacteria, psychrotolerant Pseudomonas strain Cam-1 and Mesophilic Burkholderia strain LB400. Appl. Environ. Microbiol. 67, 26692676.

Michaud, L., Di Marco, G., Bruni, V., Lo Giudice, A., 2007. Biodegradative potential and characterization of psychrotolerant polychlorinated biphenyl-degrading bacteria isolated from a coastal station in Terra Nova Bay (Ross Sea, Antarctica). Mar. Pollut. Bull. 54, 1754-1761.

Mohn, W.W., Westerberg, K., Cullen, W.R., Reimer, K.J., 1997. Aerobic biodegradation of biphenyl and polychlorinated biphenyls by Arctic soil microorganisms. Appl. Environ. Microbiol. 63, 3378-3384.

Mouz, S., Merlin, C., Springael, D., Toussaint, A., 1999. A GntR-like negative regulator of the biphenyl degradation genes of the transposon Tn4371. Mol. Gen. Genet. 262, 790799.

Peeters, K., Willems, A., 2011. The gyrB gene is a useful phylogenetic marker for exploring the diversity of Flavobacterium strains isolated from terrestrial and aquatic habitats in Antarctica. FEMS Microbiol. Lett. 321, 130-140.

Peloquin, L., Greer, C.W., 1993. Cloning and expression of the polychlorinated biphenyldegradation gene cluster from Arthrobacter M5 and comparison to analogous genes from gram negative bacteria. Gene 125, 35-40. 
Polkowska, Ż., Cichała-Kamrowska, K., Ruman, M., Kozioł, K., Krawczyk, W.E., Namieśnik, J., 2011. Organic pollution in surface waters from the Fuglebekken Basin in Svalbard. Norwegian Arctic Sensors 11, 8910-8929.

Prasad, S., Manasa, P., Buddhi, S., Tirunagari, P., Begum, Z., Rajan, S., Shivaji, S., 2014. Diversity and bioprospective potential (cold-active enzymes) of cultivable marine bacteria from the subarctic glacial fjord, Kongsfjorden. Curr. Microbiol. 68, 233-238.

Sabin, L., Maruya, K., Lao, W., Diehl, D., Tsukada, D., Stolzenbach, K., Schaff, K., 2010. Exchange of polycyclic aromatic hydrocarbons among the atmosphere, water, and sediment in coastal embayments of southern California, USA. Environ. Toxicol. Chem. $29,265-274$.

Saitou, M., Nei, M., 1987. The neighbor-joining method: a new method for reconstructing phylogenetic trees. Mol. Biol. Evol. 4, 406-425.

Shin, S.K., Kim, K.S., You, J.C., Song, B.J., Kim, J.G., 2006. Concentration and congener patterns of polychlorinated biphenyls in industrial and municipal waste incinerator flue gas, Korea. J. Hazard Mater. 133, 53-59.

Skotvold, T., Savinov, V., 2003. Regional distribution of PCBs and presence of technical PCB mixtures in sediments from Norwegian and Russian Arctic Lakes. Sci. Total Environ. 306, 85-97.

Svendsen, H., Møller, B.A., Hagen, J.O., Lefauconnier, B., Tverberg, V., Gerland, S., Ørbøk, J.B., Bischof, K., Papucci, C., Zajaczkowski, M., Azzolini, R., Bruland, O., Wiencke, C., Winther, J.G., Dallmann, W., 2002. The physical environment of Kongsfjorden-Krossfjorden, an Arctic fjord system in Svalbard. Polar Res. 21, 133-166. 
Takeda, H., Yamada, A., Miyauchi, K., Masai, E., Fukuda, M., 2004. Characterization of transcriptional regulatory genes for biphenyl degradation in Rhodococcus sp. Strain RHA1. J. Bacteriol. 186, 2134-2146.

Thompson, J.D., Higgins, D.G., Gibson, T.J., 1994. CLUSTAL W: improving the sensitivity of progressive multiple sequence alignment through sequence weighting, position-specific gap penalties and weight matrix choice. Nucleic Acids Res. 22, 46734680.

Tian, F., Yu, Y., Chen, B., Li, H., Yao, Y.F., Guo, X.K., 2009. Bacterial, archaeal and eukaryotic diversity in Arctic sediment as revealed by $16 \mathrm{~S}$ rRNA and 18S rRNA gene clone libraries analysis. Polar Biol. 32, 93-103.

Van Gerven, T., Geysen, D., Vandecasteele, C., 2004. Estimation of the contribution of a municipal waste incinerator to the overall emission and human intake of PCBs in Wilrijk, Flanders. Chemosphere 54, 1303-1308.

Wang, Z., Ma, X., Na, G., Lin, Z., Ding, Q., Yao, Z., 2009. Correlations between physicochemical properties of PAHs and their distribution in soil, moss and reindeer dung at Ny-Ålesund of the Arctic. Environ. Pollut. 157, 3132-3136.

Yakimov, M.M., Giuliano, L., Bruni, V., Scarfî, S., Golyshin, P.N., 1999. Characterization of Antarctic hydrocarbon-degrading bacteria capable of producing bioemulsifiers. New Microbiol. 22, 249-256.

Yang, X., Sun, Y., Qian, S., 2004. Biodegradation of seven polychlorinated biphenyls by a newly isolated aerobic bacterium (Rhodococcus sp. R04). J. Ind. Microbiol. Biotechnol. $31,415-442$. 
Zeng, Y.X., Zhang, F., He, J.F., Lee, S.H., Qiao, Z.Y., Yu, Y., Li, H.R., 2013. Bacterioplankton community structure in the Arctic waters as revealed by pyrosequencing of 16S rRNA genes. A. Van Leeuw. J. Microbiol. 103, 1309-1319.

Zoccolillo, L., Abete, C., Amendola, L., Ruocco, R., Sbrilli, A., Termine, M., 2004. Halocarbons in aqueous matrices from the Rennick Glacier and the Ross Sea (Antarctica). Int. J. Environ. Anal. Chem. 84, 513-522. 


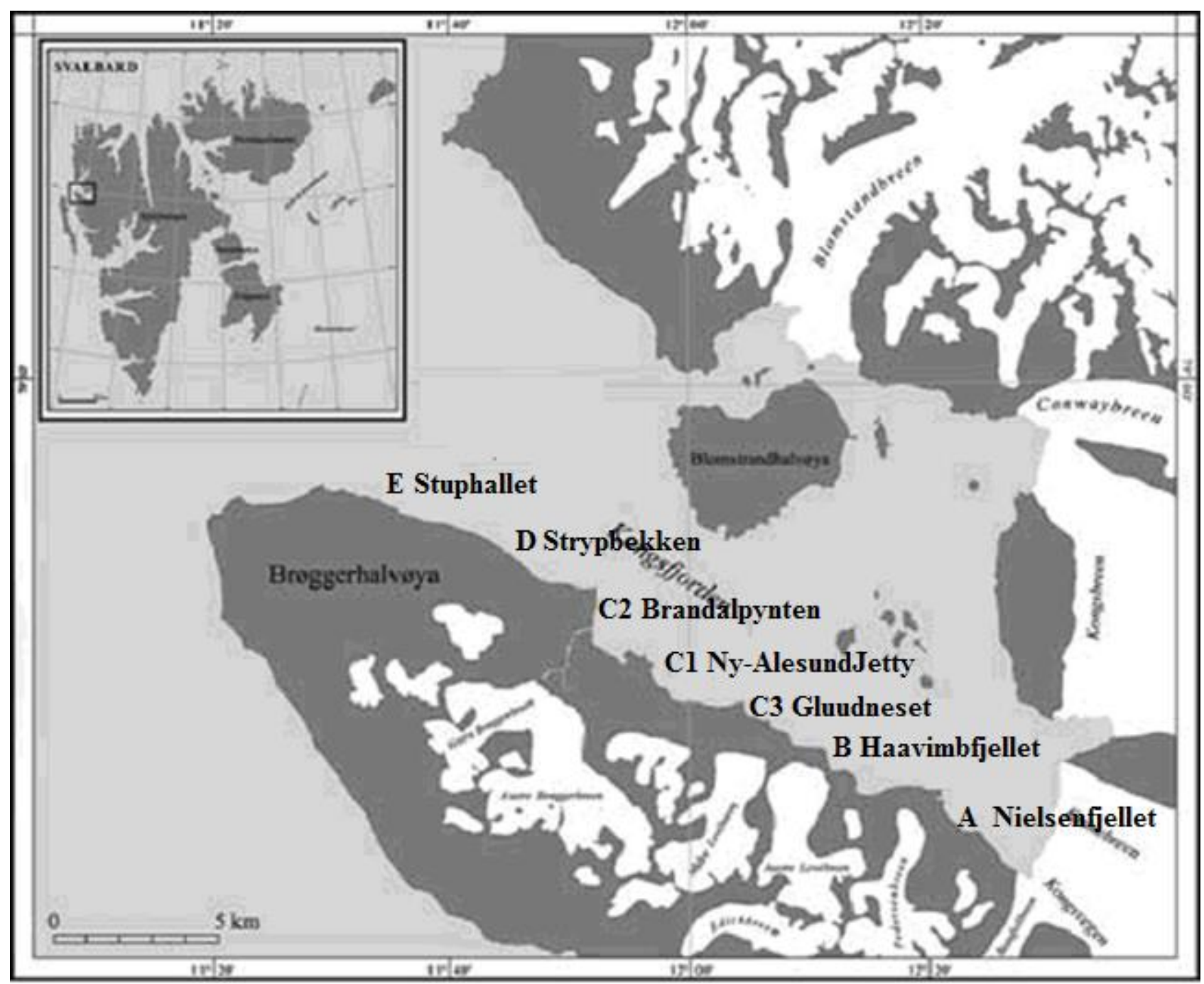

FIG 1 Sampling sites along the Kongsfjorden. 


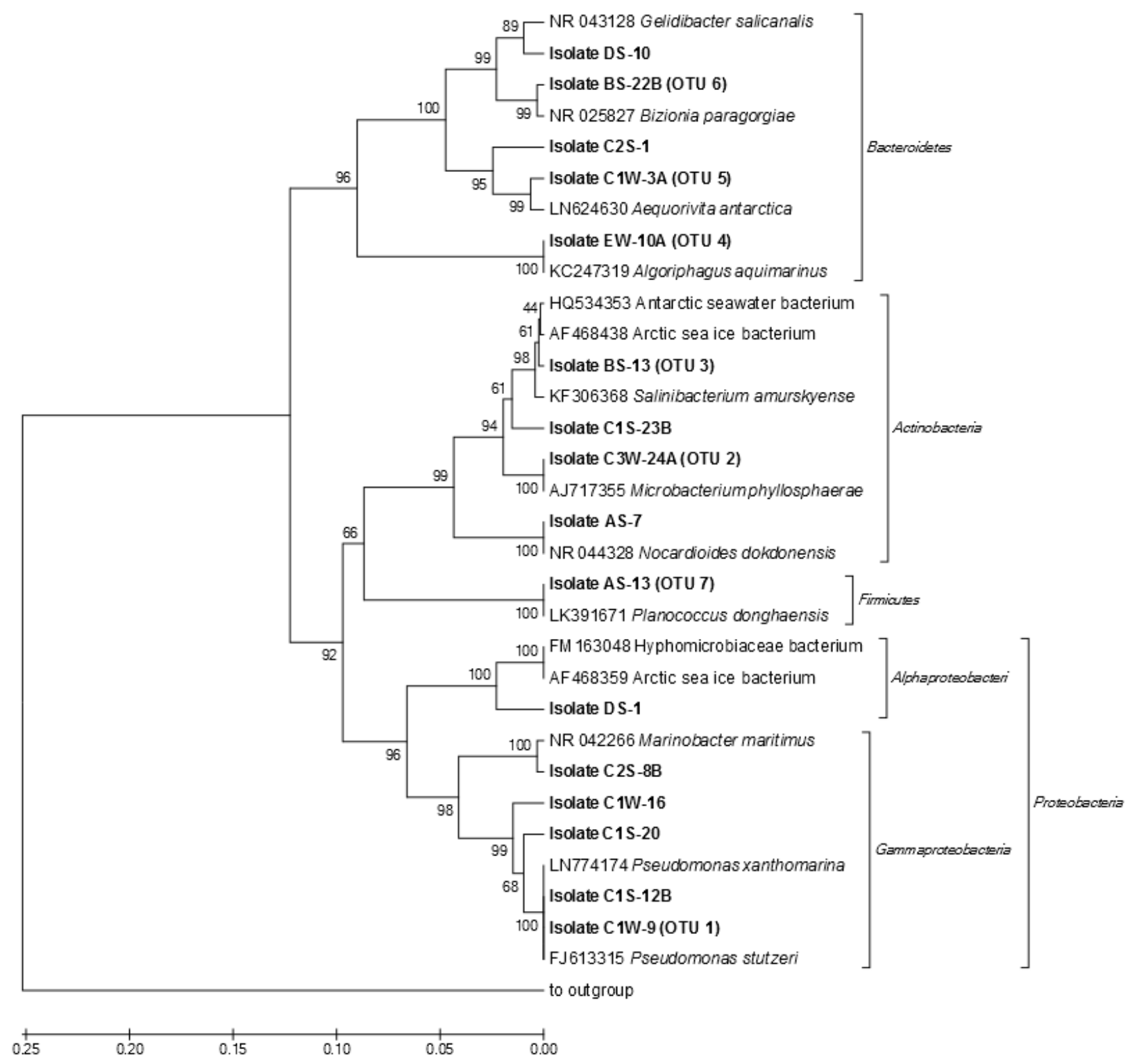

FIG 2 Rooted phylogenetic tree calculated by Jukes-Cantor distance estimation algorithm showing affiliation of PCB-oxidizing isolates to closest-related sequences from either cultivated or cloned bacteria. Percentages of 400 bootstrap resampling that supported the branching orders in each analysis are shown above or near the relevant nodes. The tree was outgrouped with 16S rRNA gene sequence of Methanocaldococcus jannaschii DSM 2661. 


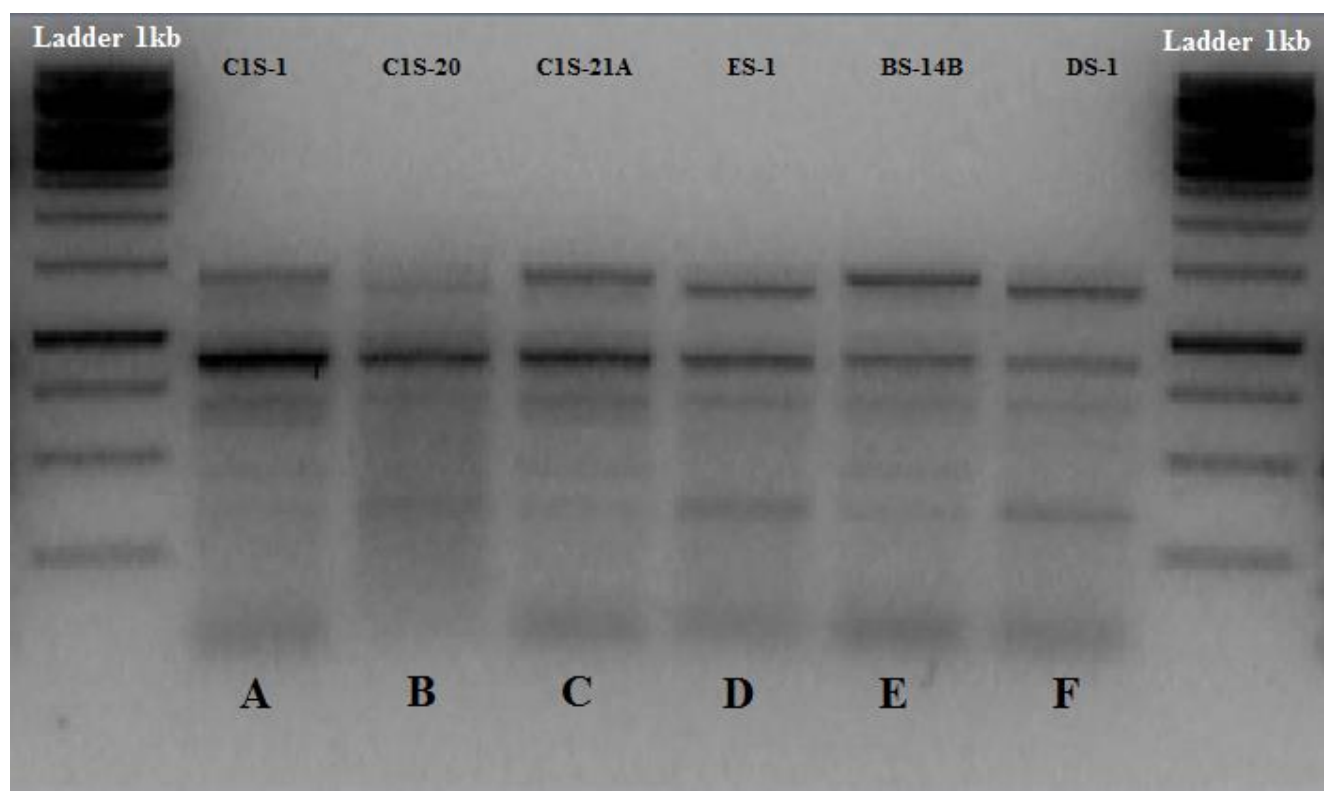

FIG 3 PCR product of $b p h A$ gene (947 bp) on agarose gel (2\%, wt/vol).

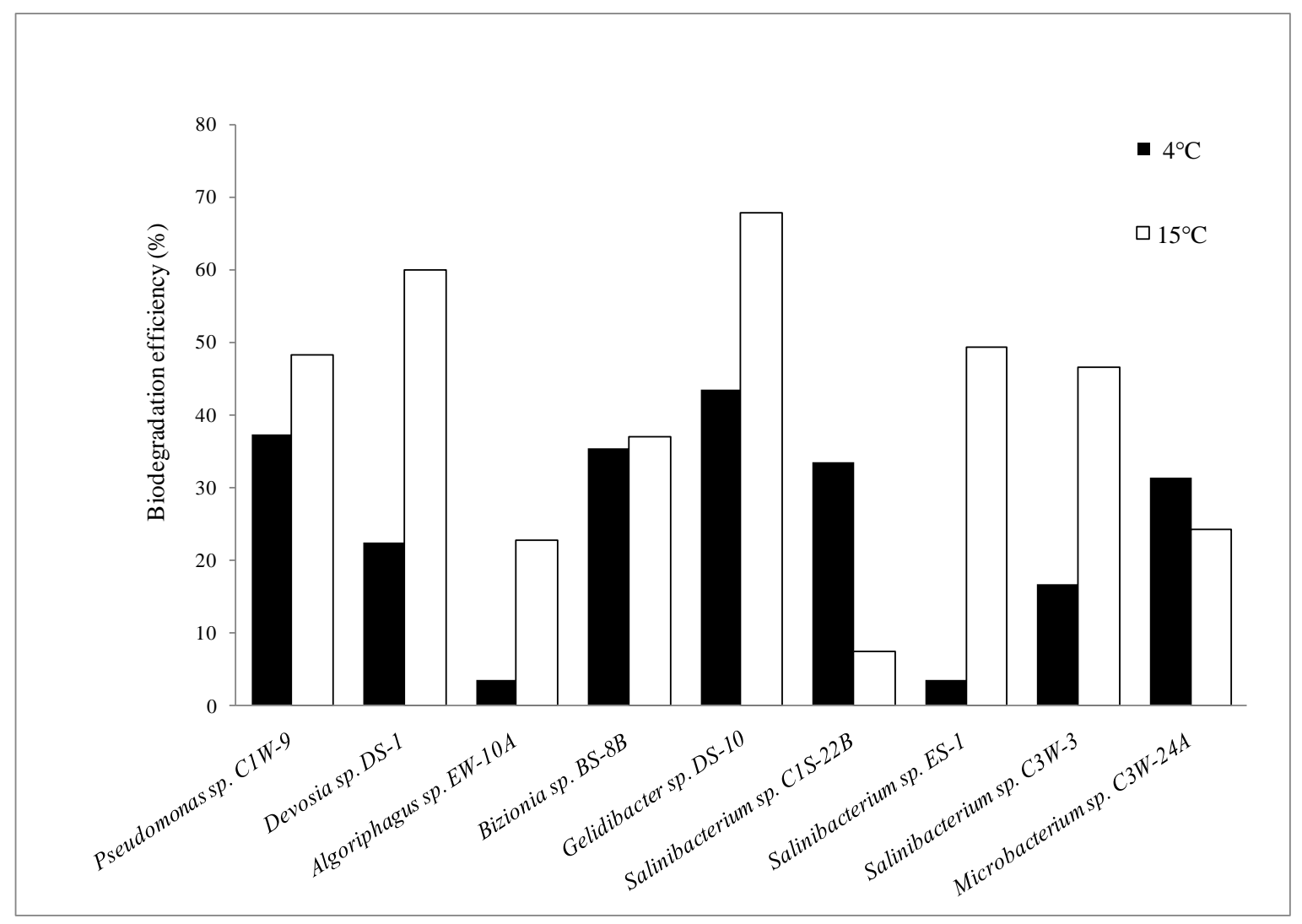

FIG 4 Biodegradation efficiency (\%) on Aroclor 1242 of Arctic bacterial isolates at 4 and $15^{\circ} \mathrm{C}$. 


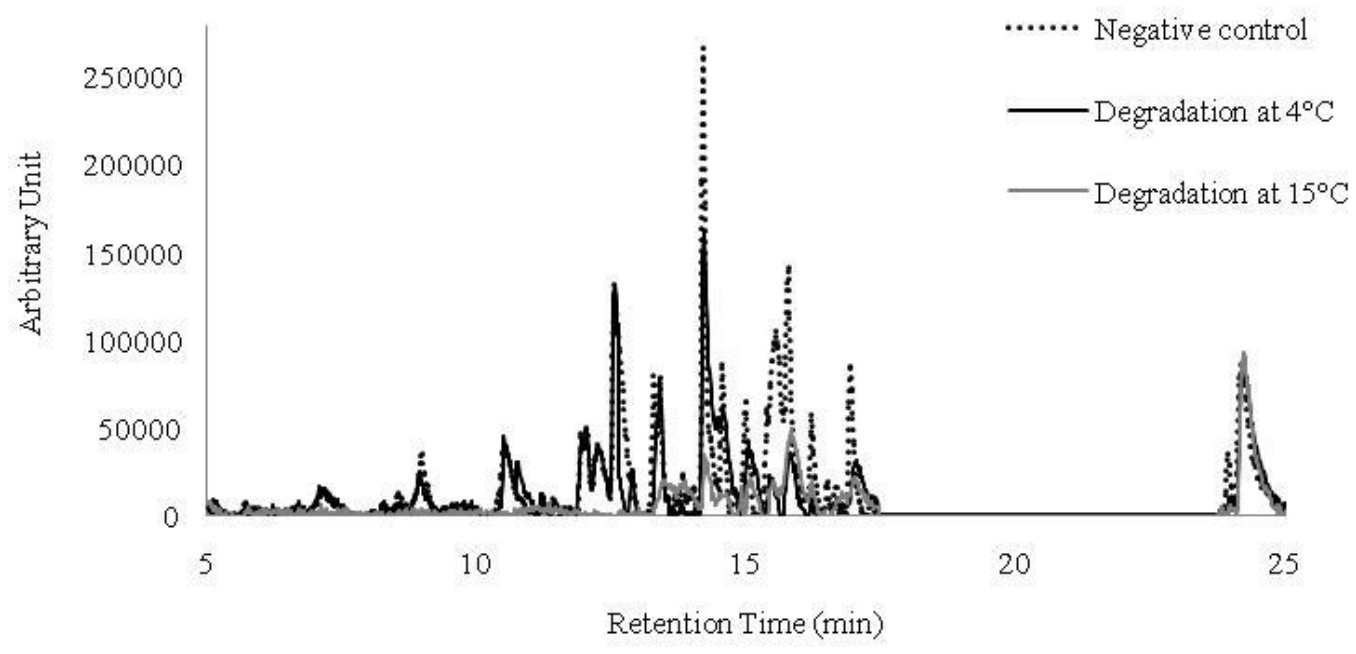

FIG 5 Example of chromatogram. Devosia sp. DS-1. 
TABLE 1 Physical and chemical parameters measured along the Kongsfjorden at sampling time.

\begin{tabular}{lccccccc}
\hline \multirow{2}{*}{ Sites } & Sample ID & Coordinates & $\begin{array}{c}\mathrm{T} \\
\left({ }^{\circ} \mathrm{C}\right)\end{array}$ & $\begin{array}{c}\mathrm{O} 2 \\
(\mathrm{ppm})\end{array}$ & $\mathrm{pH}$ & $\begin{array}{c}\text { Cond } \\
\left(\mu \mathrm{m} \mathrm{s}^{-1}\right)\end{array}$ & Salinity \\
\hline Nielsenfjellet & $\mathrm{A}$ & $78^{\circ} 52.782^{\prime} \mathrm{N}-12^{\circ} 21.208^{\prime} \mathrm{E}$ & 4 & 11.6 & 8.4 & 49800 & 24.5 \\
Haavimbfjellet & $\mathrm{B}$ & $78^{\circ} 53.67^{\prime} \mathrm{N}-12^{\circ} 13.759^{\prime} \mathrm{E}$ & 5.3 & 10.6 & 8.4 & 71760 & 35.9 \\
Ny-Alesund Jetty & $\mathrm{C} 1$ & $78^{\circ} 55.606^{\prime} \mathrm{N}-11^{\circ} 56.377^{\prime} \mathrm{E}$ & 7.9 & 10.5 & 8.5 & 45420 & 22.8 \\
Brandalpynten & $\mathrm{C} 2$ & $78^{\circ} 56.449^{\prime} \mathrm{N}-11^{\circ} 52.033^{\prime} \mathrm{E}$ & 7.5 & 10.3 & 8.4 & 53010 & 26.6 \\
Gluudneset & $\mathrm{C} 3$ & $78^{\circ} 54.861^{\prime} \mathrm{N}-12^{\circ} 01.867^{\prime} \mathrm{E}$ & 4 & 9.9 & 8.4 & 36180 & 18.1 \\
Strypbekken & $\mathrm{D}$ & $78^{\circ} 57.098^{\prime} \mathrm{N}-11^{\circ} 46.140^{\prime} \mathrm{E}$ & 5.4 & 12.5 & 8.5 & 53100 & 26.6 \\
Stuphallet & $\mathrm{E}$ & $78^{\circ} 57.656^{\prime} \mathrm{N}-11^{\circ} 42.635^{\prime} \mathrm{E}$ & 6.9 & 11.9 & 8.7 & 54120 & 27.2 \\
\hline
\end{tabular}

Table 2 PCB concentrations determined in water samples. Standard deviations ( $\mathrm{n}=9 ; 3$ field replicate and 3 instrumental replicates for each one) are reported in brackets.

\begin{tabular}{|c|c|c|c|c|c|c|c|c|c|c|}
\hline \multirow[b]{2}{*}{ Sample } & \multicolumn{8}{|c|}{ PCB Congener $\left(\mathrm{pg} \mathrm{l}^{-1}\right)$} & \multirow[b]{2}{*}{ PCB 77} & \multirow[b]{2}{*}{$\Sigma \mathrm{PCBs}$} \\
\hline & PCB 170 & PCB 195 & PCB 209 & PCB 187 & PCB 201 & PCB 180 & PCB 153 & PCB 138 & & \\
\hline AW & $1.11(0.01)$ & $0.20(0.02)$ & $0.14(0.01)$ & $0.29(0.01)$ & nd & $0.59(0.01)$ & $3.38(0.02)$ & $10.31(0.01)$ & $11.67(0.02)$ & $27.69(0.1)$ \\
\hline BW & $1.32(0.01)$ & $0.30(0.01)$ & $0.29(0.01)$ & $0.56(0.01)$ & $0.21(0.01)$ & $1.33(0.01)$ & $3.40(0.02)$ & $13.2(0.01)$ & $2.55(0.03)$ & $23.16(0.1)$ \\
\hline $\mathrm{C} 1 \mathrm{~W}$ & $1.68(0.01)$ & $0.25(0.01)$ & $0.35(0.01)$ & $0.25(0.01)$ & $0.13(0.01)$ & $2.77(0.01)$ & $1.27(0.03)$ & $3.67(0.02)$ & $3.52(0.03)$ & $13.89(\mathbf{0 . 1})$ \\
\hline $\mathrm{C} 2 \mathrm{~W}$ & $0.95(0.02)$ & $0.18(0.01)$ & $0.22(0.01)$ & nd & nd & $2.54(0.01)$ & $4.33(0.02)$ & nd & $3.41(0.03)$ & $11.63(\mathbf{0 . 1})$ \\
\hline $\mathrm{C} 3 \mathrm{~W}$ & $0.51(0.02)$ & $0.14(0.02)$ & $0.17(0.01)$ & nd & nd & $1.06(0.01)$ & $2.19(0.02)$ & $2.89(0.02)$ & $6.35(0.02)$ & $13.31(\mathbf{0 . 1})$ \\
\hline DW & nd & $0.21(0.01)$ & $0.22(0.01)$ & nd & nd & $0.82(0.01)$ & $2.41(0.02)$ & $7.36(0.02)$ & $1.29(0.02)$ & $12.31(\mathbf{0 . 1})$ \\
\hline EW & $0.69(0.01)$ & $0.51(0.01)$ & $0.39(0.01)$ & nd & $0.19(0.01)$ & $1.56(0.01)$ & $1.97(0.02)$ & $2.73(0.02)$ & $11.00(0.02)$ & $19.04(0.1)$ \\
\hline
\end{tabular}


Table 3. Number of bacterial isolates obtained from biphenyl enrichments. Isolates growing on Aroclor 1242 are in brackets.

\begin{tabular}{|c|c|c|}
\hline \multirow[b]{2}{*}{ Site } & \multicolumn{2}{|c|}{ Sample matrix } \\
\hline & Water & Sediment \\
\hline A & $4(0)$ & $15(6)$ \\
\hline B & $0(0)$ & $27(9)$ \\
\hline $\mathrm{C} 1$ & $22(6)$ & $33(8)$ \\
\hline $\mathrm{C} 2$ & $19(2)$ & $15(2)$ \\
\hline $\mathrm{C} 3$ & $28(8)$ & $11(0)$ \\
\hline $\mathrm{D}$ & $16(0)$ & $15(2)$ \\
\hline $\mathrm{E}$ & $27(1)$ & $14(1)$ \\
\hline \multirow{2}{*}{ Total } & $116(17)$ & $130(28)$ \\
\hline & \multicolumn{2}{|c|}{$246(45)$} \\
\hline
\end{tabular}


TABLE 4 16S rRNA gene sequence affiliation to their closest phylogenetic neighbors of PCB-oxidizing Arctic isolates (representative isolates of distinct phylotypes are in bold; isolates with $b p h A$ gene are underlined).

\begin{tabular}{|c|c|c|c|c|}
\hline $\mathrm{RI}^{\mathrm{a}}$ & $\mathrm{OTU}^{\mathrm{b}}$ & $\begin{array}{l}\text { Next relative by GenBank alignment } \\
\qquad\left(\mathrm{AN}^{\mathrm{c}} \text {, organism) }\right.\end{array}$ & Origin of closest isolate/clone & $\begin{array}{c}\operatorname{Hom}^{\mathrm{d}} \\
(\%)\end{array}$ \\
\hline \multicolumn{5}{|l|}{ Alphaproteobacteria } \\
\hline$\underline{\text { DS-1 }}$ & na & JX528564, Uncultured Devosia sp. clone C139300175 & Southern Ocean & 96 \\
\hline \multicolumn{5}{|l|}{ Gammaproteobacteria } \\
\hline$\underline{\underline{\text { C1W-9 }}}, \underline{\text { C1W-5 }}$, C2W-15B, C1W-15, BS-19, BS-23, $\underline{\text { C1S-1 }}, \underline{\text { C1S- }}$ & 1 & FJ613315, Pseudomonas stutzeri strain hyss62 & Deep sea sediment & 99 \\
\hline$\underline{\text { C1W-16 }}$ & na & LN774174, Pseudomonas xanthomarina 0511ARD13M5 & Air sample & 95 \\
\hline C1S-12B & na & KC294096, Pseudomonas sp. TF5 & Iron mine soil & 99 \\
\hline$\underline{\text { C1S-20 }}$ & na & KF769958, Pseudomonas sp. LM14 & Mineral sediment from Lubin copper mine & 95 \\
\hline C2S-8B & na & AJ429499, Marinobacter sp. 2sq31 & Marine sediment & 99 \\
\hline \multicolumn{5}{|l|}{ Bacteroidetes } \\
\hline C1W-3A, C3W-18A & 5 & LN624630, Aequorivita antarctica Kongs-111 & Kongsfjorden water & 99 \\
\hline C2S-1 & na & LN624630, Aequorivita antarctica Kongs-111 & Kongsfjorden water & 96 \\
\hline$\underline{\text { EW-10A }}, \underline{\text { EW-10C }}$ & 4 & KC247319, Algoriphagus aquimarinus KMM 6722 & Arctic Ocean marine sediments & 98 \\
\hline 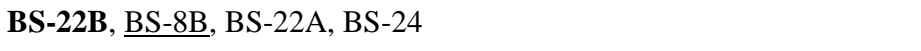 & 6 & JQ800199, Bizionia sp. KJF12-2 & Subarctic glacial Fjord, Kongsfjorden & 99 \\
\hline DS-10 & na & GAU62916, Gelidibacter algens ACAM 551 & Antarctic lacustrine and sea ice habitats & 97 \\
\hline \multicolumn{5}{|l|}{ Actinobacteria } \\
\hline $\begin{array}{l}\text { BS-13, AS-21, BS-9, } \underline{\mathrm{ES}-1}, \underline{\mathrm{BS}-14 \mathrm{~B}}, \underline{\mathrm{C} 1 \mathrm{~S}-22 \mathrm{~B}}, \mathrm{C} 1 \mathrm{~S}-5, \mathrm{C} 1 \mathrm{~W}-14 \mathrm{~A}, \\
\text { C2W-9, } \underline{\mathrm{C} 3 \mathrm{~W}-3}, \mathrm{C} 3 \mathrm{~W}-19, \mathrm{C} 3 \mathrm{~W}-22\end{array}$ & 3 & JQ799950, Salinibacterium sp. FS5-1 & Subarctic glacial Fjord, Kongsfjorden & 99 \\
\hline$\underline{\text { C1S-23B }}$ & na & KF306368, Salinibacterium amurskyense strain y182 & Ocean sediment & 96 \\
\hline C3W-24A, C3W-9B, C3W-23, C1S-13A & 2 & KC160703, Microbacterium sp. SS10.7 & Antarctic sea sediment & 99 \\
\hline AS-7 & na & HM222653, Nocardioides sp. 0701C5-1 & Deep sea sediment & 97 \\
\hline \multicolumn{5}{|l|}{ Firmicutes } \\
\hline AS-13, AS-3, AS-5, AS-9 & 7 & EU196338, Planococcus sp. NP19 & Cold saline spring, Canadian High Arctic & 99 \\
\hline
\end{tabular}

${ }^{\mathrm{a}}$ RI: representative isolates; ${ }^{\mathrm{b}}$ na: not assigned; ${ }^{\mathrm{c}}$ AN: Accession Number; ${ }^{\mathrm{d}}$ Hom: sequence homology. 
TABLE 5 Degradation of individual PCB congeners by Arctic isolates.

Biodegradation efficiency (\%)

\begin{tabular}{|c|c|c|c|c|c|c|c|c|c|c|c|c|c|c|c|c|c|c|c|}
\hline \multirow{3}{*}{$\begin{array}{l}\text { Retention } \\
\text { Time } \\
\text { (min) }\end{array}$} & \multirow{3}{*}{$\begin{array}{c}\text { Congener } \\
\text { assignement }\end{array}$} & \multirow{2}{*}{\multicolumn{2}{|c|}{$\begin{array}{c}\text { Pseudomonas } \\
\text { C1W-9 }\end{array}$}} & \multirow{2}{*}{\multicolumn{2}{|c|}{$\frac{\text { Devosia }}{\text { DS-1 }}$}} & \multirow{2}{*}{\multicolumn{2}{|c|}{$\frac{\text { Algoriphagus }}{\text { EW-10A }}$}} & \multirow{2}{*}{\multicolumn{2}{|c|}{$\frac{\text { Gelidibacter }}{\text { DS-10 }}$}} & \multirow{2}{*}{\multicolumn{2}{|c|}{$\frac{\text { Bizionia }}{\text { BS-8B }}$}} & \multicolumn{6}{|c|}{ Salinibacterium } & \multirow{2}{*}{\multicolumn{2}{|c|}{$\frac{\text { Microbacterium }}{\mathrm{C} 3 \mathrm{~W}-24 \mathrm{~A}}$}} \\
\hline & & & & & & & & & & & & \multicolumn{2}{|c|}{ C1S-22B } & \multicolumn{2}{|c|}{ ES-1 } & \multicolumn{2}{|c|}{$\mathrm{C} 3 \mathrm{~W}-3$} & & \\
\hline & & $4^{\circ} \mathrm{C}$ & $15^{\circ} \mathrm{C}$ & $4^{\circ} \mathrm{C}$ & $15^{\circ} \mathrm{C}$ & $4^{\circ} \mathrm{C}$ & $15^{\circ} \mathrm{C}$ & $4^{\circ} \mathrm{C}$ & $15^{\circ} \mathrm{C}$ & $4^{\circ} \mathrm{C}$ & $15^{\circ} \mathrm{C}$ & $4^{\circ} \mathrm{C}$ & $15^{\circ} \mathrm{C}$ & $4^{\circ} \mathrm{C}$ & $15^{\circ} \mathrm{C}$ & $4^{\circ} \mathrm{C}$ & $15^{\circ} \mathrm{C}$ & $4^{\circ} \mathrm{C}$ & $15^{\circ} \mathrm{C}$ \\
\hline 10,49 & $2,2^{\prime}$ & 53.7 & 90 & 18.1 & 96.1 & - & 67.6 & 19.9 & 91.5 & 22.2 & 29.6 & 84.2 & 79.2 & 11.8 & 93.5 & 2.8 & 88.8 & 77.4 & 78.7 \\
\hline 12,19 & 2,3 & 68.9 & 83.6 & 32.2 & 89.9 & - & 17.8 & 22.5 & 97.3 & 37.2 & - & 95.2 & 41.8 & 64.9 & 85.6 & - & 92.1 & 95.7 & 83.7 \\
\hline 13,26 & $2,2^{\prime}, 5$ & 76.3 & 92.5 & 32.4 & 98 & 61.1 & 76.8 & 74.1 & 97.6 & 58.2 & 62.8 & 89.2 & - & 75.3 & 90.7 & 38.9 & 91 & 89.9 & 86.6 \\
\hline 13,30 & $2,4,6$ & 58.6 & 58.9 & 30.4 & 69.2 & 3.5 & - & 1.1 & 32.3 & 18.5 & - & - & - & 32.9 & 46.3 & - & - & - & - \\
\hline 14,14 & $2,3 \prime, 5$ & 40.8 & 48.2 & 98.1 & 71.3 & 5.7 & - & 8.9 & 61.8 & 34.4 & 29.4 & - & - & 17.4 & 28.6 & 3.4 & 47.7 & 14.4 & - \\
\hline 14,35 & $2,2^{\prime}, 5,6$ & 9.9 & 9.9 & 5.2 & 39.3 & - & - & 19.4 & 65.3 & 62 & 26.5 & 44.8 & - & - & 32.3 & - & 59.4 & 60.3 & 15.1 \\
\hline 15,39 & $2,2^{\prime}, 3,3^{\prime}$ & 50.2 & 59.3 & 86.7 & 84.5 & 15.7 & - & 80.4 & 70.4 & 89.2 & 58.1 & 39.7 & 14.3 & 22.7 & 62.7 & 32.9 & 39.2 & 36.2 & 14.5 \\
\hline 16,08 & $2,2^{\prime}, 4,5^{\prime}$ & 49.1 & 53.7 & 63.1 & 34.2 & - & - & 64.4 & 41.4 & 57.8 & 49.1 & 13.4 & 62.2 & 26.4 & 36.5 & 59.3 & 23.9 & 40.2 & - \\
\hline 17,33 & $2,4,4^{\prime}, 6$ & 28.5 & 7.3 & 14.3 & 32.1 & - & - & 42.1 & 63.3 & 35.6 & 74.6 & 22.6 & 19.8 & - & 57 & 27.8 & 60.8 & 51.6 & 28.8 \\
\hline
\end{tabular}

